\title{
ANALISA TEKNIS PEMBANGUNAN SHIP RECYCLING YARD DI INDONESIA
}

\author{
Siti Fariya \\ Jurusan Teknik Perkapalan, Institut Teknologi Adhi Tama Surabaya \\ Surabaya, Indonesia \\ email: sitinaval@itats.ac.id
}

diterima tanggal : 10 Agustus 2018 disetujui tanggal : 13 November 2018

Abstrak

Perencanaan pengembangan konektivitas melalui penerapan tol laut memunculkan gagasan untuk menambah dan meremajakan armada kapal nasional. Salah satu target diterapkan pada kapal tua yang perlu diganti dengan yang baru. Kapal yang pada kondisi masa akhir operasi dan pada akhirnya tidak digunakan lagi dalam kegiatan operasi pelayaran dapat dilakukan kegiatan daur ulang. Dimana kegiatan daur ulang kapal adalah kegiatan pemotongan dan penghancuran kapal yang tidak digunakan lagi dengan aman dan berwawasan lingkungan (Green Ship Recycling). Kondisi kekinian industri daur ulang kapal nasional perlu dikembangkan karena masih menggunakan fasilitas sederhana yang tidak ramah lingkungan dan tidak memperhatikan keselamatan pekerja. Untukmelakukan pengembangan Ship Breaking Yard menjadi Green Ship Recycling Yard, yang sesuai dengan aturan IMO diperlukan pengembangan dalam hal: fasilitas dan teknologi penanganan material dan layout. Pemilihan fasilitas dan teknologi dilakukan dengan menggunakan metode fuzzy AHP sendangkan pemodelan layout dengan mempertimbangkan aturan IMO dan juga kondisi existing dari ship breaking yard. Hasil dari penelitian ini: potensi pasar Ship Recycling di Indonesia sangat besar. Hal in dapat dilihat dari jumlah kapal dengan lifetime diatas 25 tahun sebanyak 1.404 unit dari 6.663 unit yang terdaftar di BKI, jumlah kapal ini seharusnya harus tidak beroprasi lagi. Sendangkan untuk pemilihan teknologi ship recycling yard sebagia berikut: docking menggunakan slipway dengan Interval Value 0,3933; Deacoating menggunakan Dry Ice dengan Interval Value 0,3351; Cutting dengan Oxy-accetylene dengan Interval Value 0,5487 dan Material Handling dengan Cawler crane dengan Interval Value 0,5512. Sendangkan untuk layout didesain untuk kapal dengan kapasitas 2.500 GT berlokasi di Kamal-Kabupaten Bangkalan, Madura. Aktivitas pemisahan bahan berbahaya dan tempat pembuangan-nya dalam layout ship recycling yard menjadi hal yang harus diutamakan, karena hal ini sangat kurang diperhatikan pada ship recycling yard di Indonesia.

Kata kunci : Ship Recycling Yard, fuzzy AHP, layout.

\begin{abstract}
Planning the development of connectivity through the application of toll sea increase the ideas for adding and renovation the national fleet. One of the targets is applied to old ships that need to be replaced with the new ones.Old ships and eventually not used again can be recycled. Where ship recycling activities are cutting activities carried out in a less safe and environmentally friendly manner (Green Ship Recycling). The existing conditions of the national ship recycling industry need to be developed because they still use non-environmentally friendly facilities and work safety.Development of Ship Breaking Yard become a Green Garden Recycling Yard, based on IMO regulations requires development: facilities and material handling technology and layout. The selection of facilities and technology is done by using the fuzzy AHP method and layout by considering the material flow. The result: The market potential of ship recycling in Indonesia is high, this can be seen from the number of ships with a lifetime of more than 25 years of 1,404 of 6,663 units registered in BKI, the the vessel must be recycled. Whereas selection of ship recycling technology as follows: docking using slipway with a Value Interval of 0.3933; Deacoating using Dry Ice with a Value Interval of 0.3351; Cutting with Oxy-accetylene with 0.5487 Value Interval and Material Handling with Cawler crane with 0.5512 Value Interval. While the layout is
\end{abstract}


designed for ship with capacity 2,500 GT located in Kamal - Bangkalan Regency, Madura.The activity of separating hazardous materials and their disposal sites into layouts must be prioritized, because this is not considered by ship breaker in Indonesia.

Keyword : Ship Recycling Yard, fuzzy AHP, layout

\section{PENDAHULUAN}

Kapal mempunyai masa operasi lebih kurang 25 - 30 tahun, biaya yang dikeluarkan untuk proses maintenance membuat kapalkapal tua tersebut tidak ekonomis lagi dan digantikan oleh kapal baru sehingga proses bisnis tetap berlangsung serta mengurangi resiko kerusakan dan kecelakaan. Salah satu cara untuk membuat kapal bekas mempunyai nilai ekonomis adalah dengan melakukan proses recycling atau daur ulang dengan mengambil dan mengolah kembali material kapal bekas tersebut. Kapal dibangun dari berbagai jenis material dan $90 \%$ nya adalah baja. Sisanya terbuat dari komponen lainnya yang di dalamnya terdapat bahan yang berbahaya bagi lingkungan. Limbah dari aktifitas pembongkaran kapal bekas (ship dismantling) dan daur ulang kapal bekas (ship recycling) kini menjadi perhatian dunia. Limbah bahan beracun dan berbahaya (B3) itu, bisa berasal dari berbagai elemen badan kapal, antara lain dari cat yang dipakai, bahan anti karat, dan sebagainya. Bisa pula dari sisa bahan bakar atau muatan kapal, serta dari bahan-bahan yang dipergunakan dalam pekerjaan itu sendiri. International Maritime Organization (IMO), sebagai salah satu organisasi yang menaungi industri maritim dunia di bawah Perserikatan Bangsa - Bangsa (PBB), telah membuat IMO Guidelines On Ship Recycling yang dikeluarkan pada tahun 2009 melalui Hong Kong International Convention untuk memastikan bahwa kapal yang sedang didaur ulang setelah mencapai akhir hidup operasional mereka, tidak menimbulkan risiko yang tidak diingikan pada keselamatan dan kesehatan manusia atau lingkungan hidup [1]. Tiap tiap bagian dari ship recycling guidelines ini menyanggupi untuk memberikan efek penuh dan lengkap untuk mencegah, mengurangi, meminimalkan dan sejauh dapat dilaksanakan, mengurangi kecelakaan, luka, dan lain - lain yang merugikan kesehatan manusia maupun lingkungan yang disebabkan oleh ship recycling. Adanya ketentuan tersebut maka diperlukan sebuah galangan khusus ship recycling yang ada di Indonesia yang memenuhi ketentuan-ketentuan secara internasional maupun nasional. Mengingat potensi pasar ship recycling di Indonesia.

Berdasarkan data dari INSA - Indonesia National Shipowners Association, sejumlah 5.000 dari 13.000 unit kapal niaga nasional didominasi oleh kapal kontainer dan kapal tanker minyak mulai dari $3.000 \mathrm{dwt}$ hingga $50.000 \mathrm{dwt}$ dan $50 \%$ nya berada di kisaran 10.000 sampai $30.000 \mathrm{dwt}$, jika diasumsikan bahwa 50\% dari kapal harus didaur ulang dalam waktu 5 tahun itu berarti ada sekitar 1.250 kapal tua sebagai pasar oleh karena itu permintaan untuk daur ulang kapal atau scrapping cukup menjanjikan. Di Indonesia telah terdapat beberapa industri penutuhan kapal (Ship Breaking) namun belum mengutamakan keselamatan pekerja dan lingkungan, sehingga pada penelitian ini penulis akan membahas tentang pengembangan industri penutuhan kapal (ship breaking) menjadi industri daur ulang kapal (ship recycling) yang sesuai dengan kondisi di Indonesia. Sehingga tujuan dari penelitian ini adalah potensi pasar ship recycling, pemilihan teknologi ship recycling yar dan layoutnya.

\section{TUNJAUAN PUSTAKA}

A. Greeen Ship Recycling

Green Ship Recycling adalah Proses pengambilan material sisa kapal untuk diolah menjadi material yang dapat digunakan kembali, dengan memperhatikan keselamatan, kesehatan pekerja dan lingkungan sekitarnya maka Termasuk didalamnya mooring, beaching, dismantling, recovery of material dan reprocessing (IMO "Guidelines on Ship Recycling, Resolution A.962-23"). Sementara pengertian dari Ship Recycling Yard adalah Tempat/fasilitas daur ulang kapal yang mendapat izin dari pihak yang 
berwenang dimana galangan itu berada (IMO, Ship recycling Guideline, 2003). Proses daur ulang kapal (ship recycling) dapat dilaksanakan dengan mengandaskan (beaching) atau menyandarkan (mooring) kapal dengan tetap memperhatikan keselamatan dan kesehatan orang yang terlibat didalamnya dan dampak terhadap lingkungan sekitar.

Kapal dibangun dari berbagai jenis material dan $90 \%$ nya adalah baja. Sisanya terbuat dari komponen lainnya yang di dalamnya terdapat bahan yang berbahaya bagi lingkungan. Dalam penanganan material berbahaya dibutuhkan penilaian terhadap fungsi dari masing - masing material. Penilaian tersebut menentukan metode pengelolaan lanjutan yang dibutuhkan material. Metode pengelolaan yang dimaksud terbagi menjadi :

Reuse : Material dapat digunakan kembali dengan melihat kondisi dan kegunaan yang masih layak. Maintanance sederhana mungkin dibutuhkan.

Recycle: Material dapat digunakan kembali apabila dilakukan daur ulang terlebih dahulu.

Disposal : Material tidak memiliki nilai ekonomis sehingga hanya perlu dilakukan pembuangan.

Proses dari life cycle kapal dapat dilihat pada Gambar 1.

\section{B. Aturan mengenai Green Ship Recycling}

Beberapa standar peraturan mengenai green ship recycling adalah Basel Convention. United Nations Envirometal Programme (UNEP) di dalam Basel Convention tahun 2003 juga mengembangkan model Ship Breaking Yard beserta aktifitas di setiap zona, fungsi utama dari model ship breaking yard sesuai dengan aturan Basel Convention ini adalah :

- Membatasi material-material berbahaya

- Tempat pemisahan lanjut dari komponenkomponen kapal

- Penampungan sementara material metal dan material berbahaya

- Fasilitas tempat pembuangan terdekat

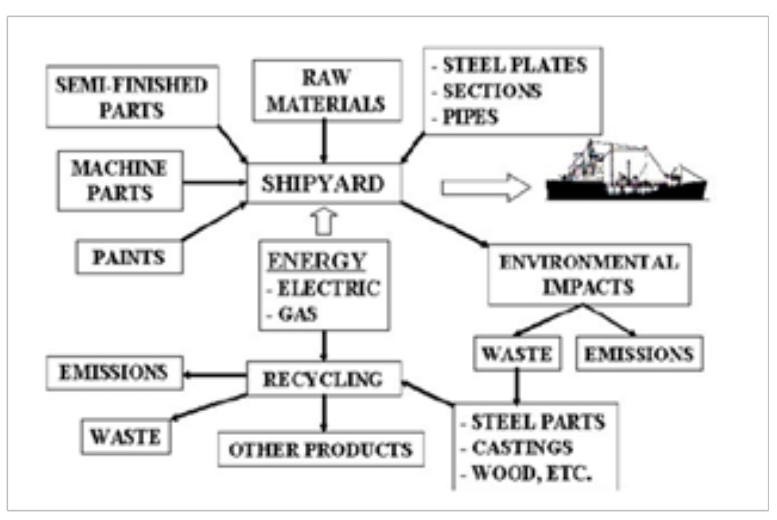

Gambar 1. Proses life cycle kapal

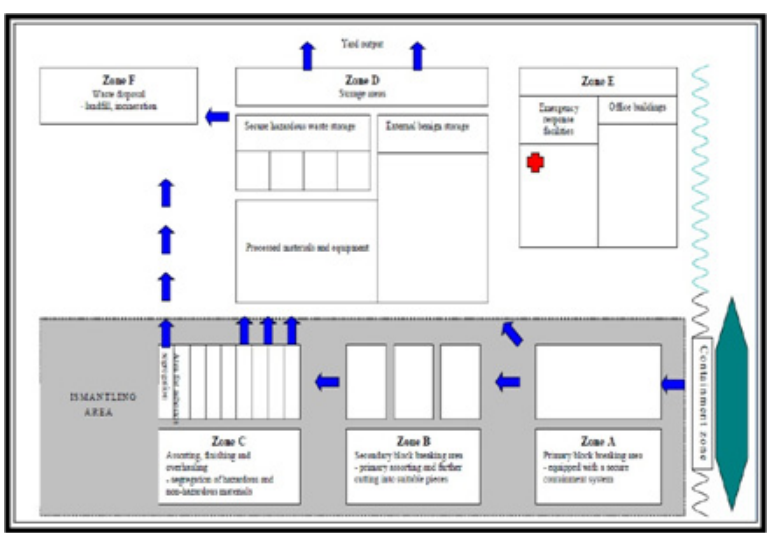

Gambar 2. Model Layout The Basel Convention

Model ship recycling yard menurut Basel Convention seperti pada Gambar 2 di atas.

Didalam setiap zona terdapat aktfitasaktifitas pada saat awal proses (input) sampai akhir proses (output), aktifitas tersebut terlihat pada tabel berikut :

Tabel I. Aktifitas Pada Ship Recycling Yard

\begin{tabular}{|c|c|c|c|}
\hline Zona & Aktifitas & $\begin{array}{c}\text { Dampak } \\
\text { Lingkungan }\end{array}$ & $\begin{array}{c}\text { Dampak } \\
\text { Kesehatan } \\
\text { dan } \\
\text { Keselamatan }\end{array}$ \\
\hline \multirow{5}{*}{ Zona A } & $\begin{array}{l}\text { Pemindahan minyak sisa } \\
\text { dan cairan di kapal }\end{array}$ & $\begin{array}{l}\text { Pencemaran } \\
\text { BBM dan } \\
\text { pelumas }\end{array}$ & Asbestos \\
\hline & $\begin{array}{l}\text { Pengambilan peralatan } \\
\text { layak pakai }\end{array}$ & $\begin{array}{c}\text { Pencemaran } \\
\text { minyak sisa } \\
\text { dan ballast } \\
\text { kotor } \\
\end{array}$ & $\begin{array}{l}\text { Gas beracun, } \\
\text { seperti } \mathrm{CO} 2 \text {. }\end{array}$ \\
\hline & $\begin{array}{c}\text { Pemotongan kapal menjadi } \\
\text { beberapa bagian besar }\end{array}$ & $\begin{array}{l}\text { Cat dan } \\
\text { coating }\end{array}$ & $\begin{array}{c}\text { Resiko } \\
\text { kebakaran }\end{array}$ \\
\hline & $\begin{array}{c}\text { Pemindahan asbestos dan } \\
\text { batteries }\end{array}$ & Heavy metal & Radiasi \\
\hline & $\begin{array}{l}\text { Pengosongan sistem } \\
\text { pemadam kebakaran dan } \\
\text { CFC dari pendingin }\end{array}$ & PCB & \\
\hline
\end{tabular}




\begin{tabular}{|c|c|c|c|}
\hline \multirow{2}{*}{ Zona B } & $\begin{array}{l}\text { Area penyortiran utama } \\
\text { komponen }\end{array}$ & $\begin{array}{l}\text { Cat dan } \\
\text { coating }\end{array}$ & Asbestos \\
\hline & $\begin{array}{c}\text { Pemotongan lanjut menjadi } \\
\text { bagian yang lebih kecil }\end{array}$ & РСВ & Gas beracun \\
\hline \multirow{4}{*}{ Zona C } & $\begin{array}{c}\text { Penyortiran akhir } \\
\text { komponen dan peralatan }\end{array}$ & $\begin{array}{c}\text { Pencemaran } \\
\text { BBM dan } \\
\text { pelumas }\end{array}$ & Asbestos \\
\hline & $\begin{array}{l}\text { Pemisahan material } \\
\text { composite }\end{array}$ & PCB & Gas beracun \\
\hline & $\begin{array}{c}\text { Penyiapan material yang } \\
\text { dijual }\end{array}$ & & $\begin{array}{l}\text { Resiko } \\
\text { ledakan }\end{array}$ \\
\hline & $\begin{array}{c}\text { Perbaikan material yang } \\
\text { masih layak pakai }\end{array}$ & & \\
\hline \multirow[t]{2}{*}{ Zona D } & $\begin{array}{c}\text { Pencatatan material yang } \\
\text { dihasilkan }\end{array}$ & $\begin{array}{c}\text { Pencemaran } \\
\text { BBM dan } \\
\text { pelumas } \\
\end{array}$ & Asbestos \\
\hline & & РCB & $\begin{array}{l}\text { Resiko } \\
\text { ledakan }\end{array}$ \\
\hline \multirow[b]{2}{*}{ Zona E } & Kerja administrasi & & \\
\hline & $\begin{array}{l}\text { Tempat pemberian } \\
\text { pertolongan kecelakaan }\end{array}$ & & \\
\hline \multirow[t]{3}{*}{ Zona F } & Penimbunan sampah & $\begin{array}{c}\text { Kebocoran } \\
\text { cairan } \\
\text { beracun }\end{array}$ & $\begin{array}{l}\text { Cairan } \\
\text { beracun }\end{array}$ \\
\hline & Pembakaran & & Asbestos \\
\hline & Pengolahan air & & \\
\hline
\end{tabular}

\section{Pemodelan Layout Ship Breaking Yard Berdasarkan International Labour Organization (ILO)}

ILO yang merupakan organisasi perburuhan dunia dibawah Perserikatan Bangsa - Bangsa, mengatur tentang perlindungan pekerja dalam lingkungan ship recycling. Mengingat bahwa pekerjaan dan lingkungan kerja ship recycling sangat berbahaya dan memiliki tingkat kecelakaan yang cukup tinggi.

International Labour Organization dalam aturan Safety and Health in Shipbreaking 2004 telah mengembangkan Model Layout Ship Breaking Yard berdasarkan konfigurasi zona fasilitas pemotongan kapal yang ada atau topography lokasi baru yang akan dibangun. pada Gambar 3 merupakan layout berdasarkan zona secara umum.

Sebagai tambahan dari zona yang sudah diidentifikasi, zona baru untuk "Pengangkutan/ Penanganan material" di setiap area telah ditambahkan dalam daftar sebagai zona $\mathrm{T}$. Keterangan seperti terdapat dalam tabel 2.

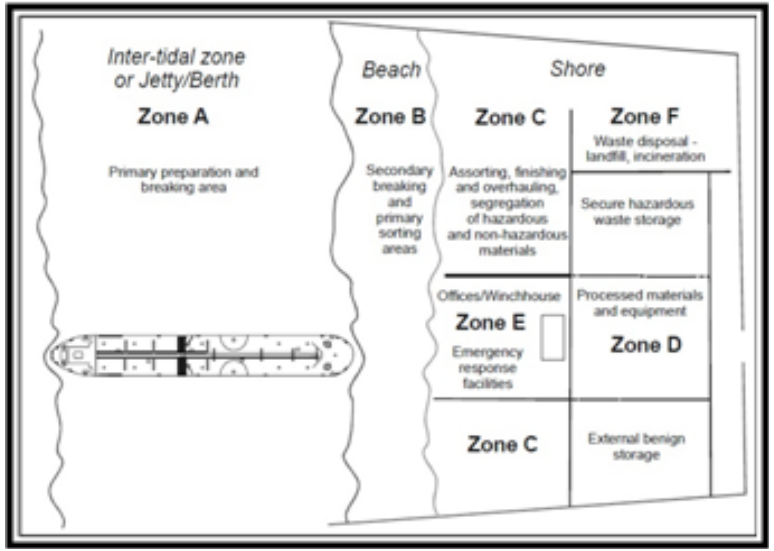

Gambar 3. Model Layout ILO

Tabel 2. Zona Dalam Ship Recycling Yard

\begin{tabular}{|l|l|}
\hline Zona & Deskripsi \\
\hline Zona A & Area persiapan awal dan pemotongan \\
\hline Zona B & Area-area peilahan utama dan pemotongan lanjutan \\
\hline Zona C & $\begin{array}{l}\text { Pemilahan, penyelesaian dan perbaikan, pemisahan } \\
\text { material berbahaya }\end{array}$ \\
\hline Zona D & Peralatan dan material yang telah diproses \\
\hline Zona E & $\begin{array}{l}\text { Fasilitas untuk merespon keadaan darurat, } \\
\text { perkantoran, dan gudang }\end{array}$ \\
\hline Zona F & Pembungan sampah, landafill, incineration \\
\hline Zona $\mathrm{T}$ & Pengangkut/ Penanganan material \\
\hline
\end{tabular}

\section{METODE PENELTIAN}

Penelitian ini bertujuan untuk merencanakan pengembangan Ship Breaking Yard menjadi Green Ship Recycling Yard dari segi metode, teknologi, dan layout. Serta melakukan analisis kelayakannya dari sisi ekonomis. Dimana metode yang digunakan untuk merencanakan pengembangannya adalah pemilihan fasilitas dan teknologi dengan menggunakan AHP, dan penyusunan layout berdasarkan material flow. Diagram alir penelitian dapat dilihat pada gambar di bawah ini. 


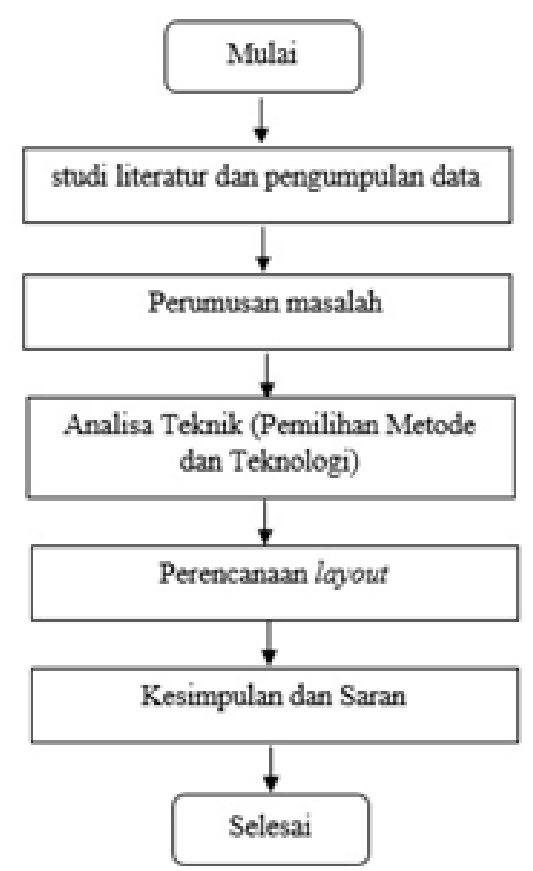

Gambar 4. Flowcart.

\section{A. Potensi Pasar Ship Recycling di Indonesia}

Kapal - kapal yang berbendera Indonesia dengan ukuran panjang antar garis tegak depan dan belakang 20 meter atau lebih atau tonase kotor GT.100 atau lebih atau yang digerakkan dengan tenaga penggerak utama 250 PK atau lebih dan kapal berbendera asing yang berubah menjadi bendera Indonesia, wajib diklaskan pada Biro Klasifikasi Indonesia (BKI). Jumlah kapal yang teregister di BKI sampai dengan akhir maret 2011 kurang lebih sebanyak 11,837 kapal, 6,663 Kapal $(56,29 \%)$ dengan berstatus aktif (sumber: CD Register BKI tahun 2011), 4,267 kapal (36,05\% ) dengan berstatus pencabutan klas dan $907 \mathrm{Kapal}$ mengalami penangguhan klas (sumber : BKI). Distribusi Jumlah kapal bersasarkan lifetime kapal dapat dilihat pada Gambar 5 berikut ini:

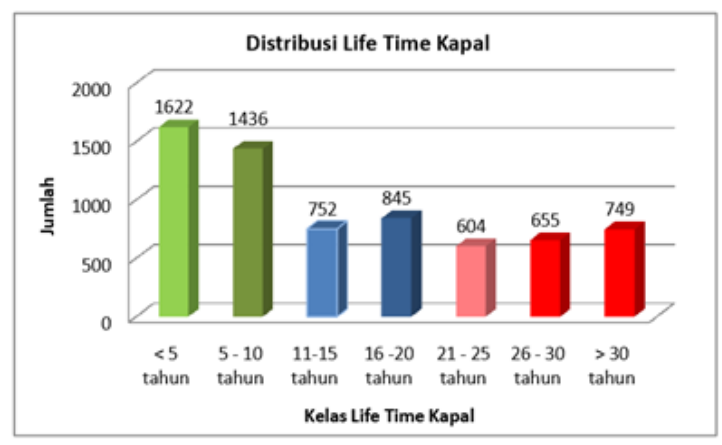

Gambar 5: Distribusi Lifetime kapal di Indonesia

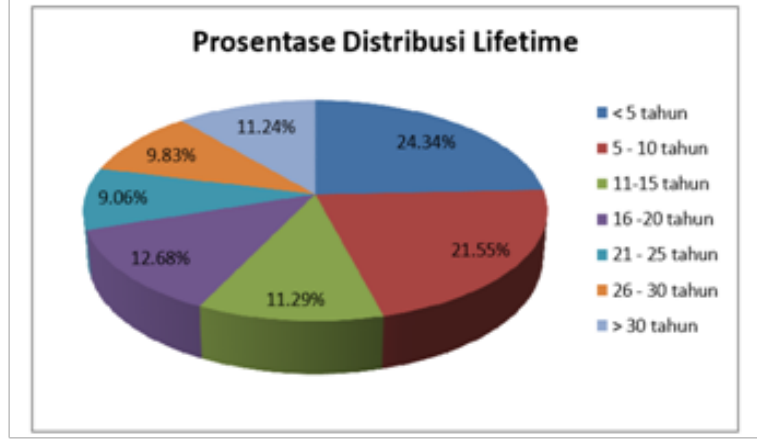

Gambar 6: Prosentase Distribusi Lifetime

Dari sebaran jumlah kapal diatas, berdasarkan tahun pembuatan dan pengurangan dilakukan pada tahun 2015. Maka untuk kapal dengan tahun pembuatan dibawah tahun 1985 atau berumur $\geq 25$ tahun berjumlah 1.404 kapal atau sebesar $21.07 \%$ dari total kapal aktif. Jumlah ini merupakan suatu potensi yang besar kapalkapal tua yang akan masuk tahapan recycling. Berikut adalah prosentase kapal kapal yang aktif di Indonesia berdasarkan lifetime adalah sebagai berikut pada Gambar 6 di atas.

Secara keseluruhan tipe kapal yang terdaftar pada BKI dibagi atas 7 (tujuh) kelompok besar dengan rincian 1. Kelompok Passanger \& Ferry, 2. Cargo Ship, 3. Bulk Carrier, 4. Container Ship, 5. Tankers, 6. Barges, 7. Other. Disetiap kelompok kapal terdistribusi berdasarkan type, GT dan tahun pembuatan, jumlah kapal terbanyak disetiap kelompok dapat dilihat dalam Tabel 3 berikut ini:

Tabel 3. Jumlah Kapal Berdasarkan Kelas Umur Kapal

\begin{tabular}{|c|c|c|c|c|c|c|c|c|c|}
\hline \multirow[b]{2}{*}{ Z } & \multirow[b]{2}{*}{ 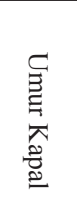 } & \multicolumn{8}{|c|}{ Jumlah Kapal } \\
\hline & & 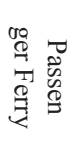 & 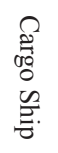 & 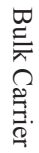 & 唟. & 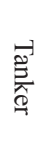 & $\begin{array}{l}\square \\
\stackrel{\#}{0} \\
0 \\
0 \\
0\end{array}$ & 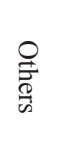 & $\stackrel{\overrightarrow{0}}{\stackrel{0}{D}}$ \\
\hline 1 & $\begin{array}{c}<5 \\
\text { tahun }\end{array}$ & 45 & 20 & 0 & 24 & 18 & 844 & 671 & 1622 \\
\hline 2 & $\begin{array}{c}5-10 \\
\text { tahun }\end{array}$ & 45 & 22 & 0 & 12 & 17 & 656 & 684 & 1436 \\
\hline 3 & $\begin{array}{l}11-15 \\
\text { tahun }\end{array}$ & 25 & 23 & 3 & 18 & 36 & 315 & 332 & 752 \\
\hline 4 & $\begin{array}{l}16-20 \\
\text { tahun }\end{array}$ & 68 & 63 & 3 & 20 & 73 & 316 & 302 & 845 \\
\hline 5 & $\begin{array}{l}21-25 \\
\text { tahun }\end{array}$ & 52 & 226 & 8 & 14 & 77 & 106 & 121 & 604 \\
\hline 6 & $\begin{array}{l}26-30 \\
\text { tahun }\end{array}$ & 41 & 244 & 19 & 28 & 86 & 67 & 170 & 655 \\
\hline
\end{tabular}




\begin{tabular}{|c|c|c|c|c|c|c|c|c|c|}
\hline 7 & $\begin{array}{c}>30 \\
\text { tahun }\end{array}$ & 43 & 209 & 34 & 33 & 56 & 109 & 265 & 749 \\
\hline \multicolumn{2}{|c|}{ Total } & 391 & 807 & 67 & 149 & 363 & 2413 & 2545 & 6663 \\
\hline
\end{tabular}

\section{B. Teknologi Daur Ulang Kapal yang Sesuai dengan Kondisi di Indonesia}

Dari Pengolahan data menggunakan metode AHP, didapat Teknologi yang dapat direkomendasikan dalam ship recycling antara lain Docking system yaitu Slipway, Cutting System yaitu Oxyacetylene, Material Handling System yaitu Crawler crane. De-coating System yaitu Dry Ice. Dengan perangkingan sebagai berikut :

Tabel 4. Pemilihan Teknologi Daur Ulang Dengaan Metode AHP

\begin{tabular}{|c|c|c|c|}
\hline Process & $\begin{array}{c}\text { Alternative } \\
\text { Technology }\end{array}$ & $\begin{array}{c}\text { Integral } \\
\text { Value }\end{array}$ & Rank \\
\hline \multirow{4}{*}{ Docking } & Slipway & 0,3933 & 1 \\
\cline { 2 - 4 } & Dry Dock & 0,3925 & 2 \\
\cline { 2 - 4 } & Wet Basin & 0,3837 & 3 \\
\hline \multirow{4}{*}{ Cutting } & Dry Ice & 0,3351 & 1 \\
\cline { 2 - 4 } & Soda blasting & 0,3337 & 2 \\
\cline { 2 - 4 } & Hydro blasting & 0,3129 & 3 \\
\hline & Oxy-accetylene & 0,5487 & 1 \\
\cline { 2 - 4 } & Water jet & 0,5478 & 2 \\
\cline { 2 - 4 } & Mobile shear & 0,5424 & 3 \\
\hline \multirow{3}{*}{$\begin{array}{c}\text { Material } \\
\text { handling }\end{array}$} & Cawler crane & 0,5512 & 1 \\
\cline { 2 - 4 } & Mobile crane & 0,5324 & 2 \\
\cline { 2 - 4 } & Fix crane & 0,5237 & 3 \\
\hline
\end{tabular}

Kriteria dan sub-kriteria pemilihan teknologi Ship Recycling Yard menggunakan hasil penelitian yang dilakukan oleh beberapa institusi/ kelompok antara lain: University of Strathclyde, University of Patras, Naftosol SA, Marine and Industral Construction, Leyal of Turkey, Ship Dismantling\& Recycling. Deskripsi Kriteria dan Sub Kriteria adalah sebagai berikut :

Kriteria Resiko terhadap Keselamatan dan Kesehatan

Sub Kriteria Pengaruh Material Berbahaya

Sub Kriteria Accident/ Incident

Sub Kriteria Ergonomics

Kriteria Resiko terhadap Lingkungan
Sub Kriteria Pengurangan Pencemaran Udara

Sub Kriteria Pengurangan Pencemaran air laut/ permukaan

Sub Kriteria Pengurangan Pencemaran soil/ sedimen

Sub Kriteria Kontrol HAZMAT

Kriteria Biaya dan Pendapatan

Sub Kriteria Pendapatan

Sub Kriteria Biaya operasi + perawatan

Sub Kriteria Biaya Investasi

Sub Kriteria Biaya dampak dari lingkungan

Kriteria Internalities

Sub Kriteria Kemampuan dan keahlian personil

Sub Kriteria Training

Sub Kriteria Pengetahuan akan teknologi

Kriteria Externalities

Sub Kriteria Image Perusahaan

Sub Kriteria Pemenuhan Aturan

\section{Perencanaan Layout Green Ship Recycling Yard}

Lokasi Ship recycling yard yang dipilih di Kamal-Kabupaten Bangkalan, Madura. Lokasi tersebut merupakan industri pemotongan kapal terbesar di Indonesia. Berdasarkan hasil data yang diperoleh ukuran kapal yang terbesar yang pernah di-scrap di tempat tersebut adalah 2.350 GT dengan rata-rata ukuran utama kapal: LOA: 104 m, B: 15 m, H: 9 m dan T: $7 \mathrm{~m}$.

Berdasarkan hasil pengamatan dan wawancara yang dilakukan, proses pemotongan kapal di KamalKabupatan Bangkalan-Madura dapat dibagi menjadi beberapa langkah berikut: (1) kedatangan kapal, kapal langsung ditarik ke pantai dengan menggunakan crane, untuk memudahkan penarikan air ballast kapal langsung dibuang ke laut. (2) Pemotongan, pemotongan kapal dibagi menjadi dua lokasi, di atas kapal dengan ukuran besar dan di darat (pemotongan kedua) dengan ukuran lebih kecil. Pemotongan dimulai dari ceruk haluan atas, tiang depan kapal, ceruk haluan bawah, penutup palkah dan lambung kapal di atas garis air, bangunan atas dan navigation deck, bagian kamar mesih dan buritan kapal dan terakhir adalah bagian lambung dibawah garis air dimana kapal ditarik ke darat untuk dipotong 
pada bagian double bottom. (3) Penyortiran bahan yang bisa dipakai, sampah dan material yang berbahaya, dilakukan bersamaan pada saat pemotongan, helper membersihkan perabotan yang masih menempel seperti kayu, triplek, dan lain-lain langsung dibuang ke laut melalui jendela. Sendangkan untuk tangki bahan bakar dan pelumas dikosongkan untuk dijual, apabila jumlah bahan bakar sedikit, maka akan dibuang langsung ke laut. Untuk material yang tidak diperlukan dan berbahaya, ship recycling yard tidak memiliki tempat khusus. (4) pengangkutan dan penanganan material untuk di bawa ke pabrik.

Oleh karena penanganan air ballast, sampah dan bahan bakar, atau pelumas dan material berbahaya lainnya tidak ada perlakuan khusus, maka layout ship recycling yarddititikberatkan pada zona $\mathrm{C}$ dan $\mathrm{F}$ pada aturan IMO tentang layout ship recycling yard. Layout tersebut dapat dilihat pada gambar 7 berikut.

Ukuran lahan layout 45 m x 40 meter, dengan kampasitas maksimum kapal yang potong adalah 2.500 GT. Dimana zonasi dari layout sebagai berikut:

- Zone A, area pasang surut air laut sebagai area persiapan awal dan pemotongan, ukurannya $36 \mathrm{~m}$ $\mathrm{x} 40 \mathrm{~m}$

- Zone B, area penyortiran utama dan pemotongan lanjut, ukurannya $16 \mathrm{~m}$ x $40 \mathrm{~m}$.

- Zone C, area pemilahan, penyelesaian dan perbaikan, pemisahan material berbahaya, ukurannya $12,5 \mathrm{~m}$ x 13,5 m.

- Zone F, area penimbunan sampah, pembakaran, dan pengolahan air yang berbahaya untuk lingkungan, ukurannya 12,5 m x 13,5 m.

- Zona D dan $\mathrm{T}$, area pencatatan material yang dihasilkan (D) dan pengangkutan dan penanganan material untuk dibawa ke pabrik besi (F).

- Zona E, fasilitas klinik darurat, perkantoran dan gudang.

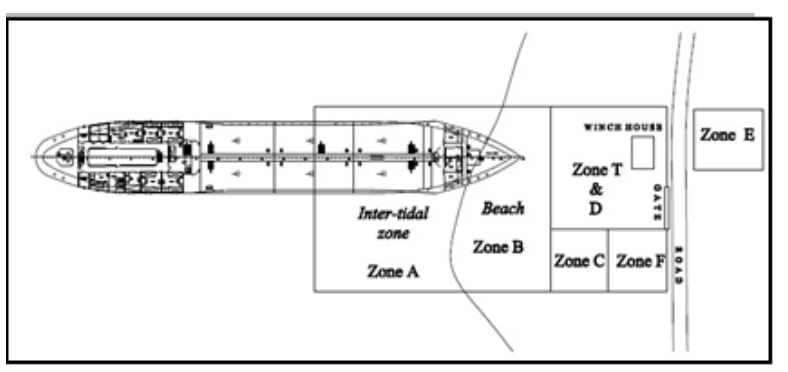

Gambar 7.Layout ship recycling yard

\section{KESIMPULAN}

Potensi pasar Ship Recycling dapat dilihat dari jumlah kapal dengan lifetime diatas 25 tahun sebanyak 1.404 unit dari 6.663 unit yang terdaftar di BKI, jumlah kapal ini seharusnya harus dipensiunkan, sehingga permintaan untuk galangan pemotongan kapal akan terus meingkat. Sendangkan untuk pemilihan teknologi ship recycling yard adalah: docking menggunakan slipway dengan interval Value 0,3933; Deacoating menggunakan Dry Ice dengan interval Value 0,3351; Cutting dengan Oxy-accetylene dengan interval value 0,5487 dan material handling dengan Cawler crane dengan interval Value 0,5512. Layout didesain untuk kapal dengan kapasitas 2.500 GT berlokasi di Kamal - Kabupaten Bangkalan, Madura. Aktivitas pemisahan bahan berbahaya dan tempat pembuangan-nya dalam Layout ship recycling yard menjadi hal yang harus diutamakan, karena hal ini sangat kurang diperhatikan pada ship recycling yard di Indonesia.

\section{DAFTAR PUSTAKA}

[1] Guidelines for the Development of the Ship Recycling Plan, adopted by Resolution MEPC.196(62), IMO, 2011

[2] Asolekar, S.R., 2012. Greening of ship recycling in India: upgrading facilities in Alang. In: The Proceedings of " 7 th Annual Ship Recycling Conference" Organized by Informa Maritime Events and Lloyd's List, UK and Held in Londonduring 19th \& 20th June, 2012.

[3] Basha, S., Gaur, P.M., Thorat, R.B., Trivedi, R.H., Mukhopadhyay, S.K., Anand, N.,Desai, S.H., Mody, K.H., Jha, B. Heavy metal content of suspended particulatematter atWorld's largest ship-breaking yard, Alang-Sosiya, India. 2007

[4] Draft Guidelines for safe and environmentally sound ship recycling. Part 1, submitted by Japan. 2013

[5] Guidelines for the Development of the Inventory of Hazardous Material, adopted by Resolution RESOLUTION MEPC.269 (68), IMO, 2015

[6] Guidelines for Safe and Environmentally Sound Ship Recycling, adopted by Resolution 
MEPC.210(63), IMO, 2012

[7] Guidelines for the Authorization of Ship Recycling Facilities, adopted by Resolution MEPC.211(63), IMO, 2012

[8] Hadjistassou, C.K., International Maritime Organization: Rethinking Marine Environmental Policy. Unpublished Master Thesis. Massachusetts Institute of Technology. 2004 